\title{
AGRICULTURAL EDUCATION AND RESTRUCTURING
}

\author{
${ }^{1}$ FATI JALO IBRAHIM AND ${ }^{2}$ Prof. FARAUTA, K. G.
}

\begin{abstract}
Increasing awareness of the important of vocational agricultural education has drive various regimes in government and education to embark on several review of agricultural curriculum at both secondary and tertiary institutions and as well as a good and profitable way of life when properly practiced. Unfortunately, in spite of the various efforts by government and other stake holders, it had been widely reported that agriculture in schools had been a failure. Agricultural education and restructuring are the focus of this study and the components for restructuring agricultural education programs are general agricultural education, linkage of agricultural education to the society and small agricultural business management and entrepreneurial training. The study also discussed the need for restructuring agricultural education, objectives of agricultural education, agricultural education/learning, shortfalls in current secondary and tertiary agricultural education, recommendations and suggestions were made in achieving sustainable development through vocational agricultural education.
\end{abstract}

\section{Introduction}

Agricultural education essentially refers to systematic program of formal and informal instructions for students in agriculture, out of schools youths, post-high school youths and established farmers, organized for the purpose of improving methods of production and rural living (Igwe,2010). Agricultural Education is aimed at providing teachers with adequate skills needed for imparting agricultural skills, knowledge and attitude to large scale as well as subsistent farmers and students at all levels. Agricultural Education is a Vocational education programme designed to prepare individual with skills, attitudes and knowledge required by individuals. It can also serve as a tool for restructuring individuals to meet or solve their socio-economic problems in life. Agricultural Education is a continuous and creative process by equipping children with spiritual moral and material knowledge, Agricultural Education releases capacities, develops analytical abilities, confidence in himself, will power and goal setting competencies and instills vision that will enable him to become self motivating agent of social change, serving the best interest of the community. Increasing awareness of the important of vocational agricultural education has drive various regimes in government and education to embark on several review of agricultural curriculum at both secondary and tertiary institutions and as well as provided policies and incentives towards motivating young ones to study and engage in agricultural policies. Unfortunately, in spite of the various efforts by government and other stake holders, it had been widely reported that agriculture in schools had been a failure (Olowa, 2002) due to the following factors:

Agricultural curriculum was not geared towards scientific large scale production; There were few qualified teachers; Instructional materials were either non-existent or imported from areas were physical and economic conditions were very different; Using practical work as a means of punishing students; There were minimal administrative supervision and Poor funding. 
Agricultural Education as a course of study in primary school originated as rural education in the early thirties (Okorie 2001).Although many schools at that time had farms and gardens there was little attempt to coordinate the programme or give it a functional approach. The farm was mismanaged as all the children were sent out to work on the farm at the same time with little supervision. This was later modified and given practical approach whereby each class was allocated to a plot and well supervised. One major contribution of the elementary agriculture is building of desirable attitudes towards farming. At both junior secondary school level (JSS) and senior secondary school (SSS) students offer Agriculture as the 6-3-34 system of education curriculum gave the subject prominence by including it among the core subjects.

\section{Objectives of Agricultural Education}

i. To stimulate and sustain students interest in agriculture.

ii. To enable students acquire basic knowledge and skills in agriculture.

iii. To enable students intergrate knowledge and practical skills.

iv. To prepare students for further studies in agriculture.

v. Agricultural Production Courses is to equip students with more practical and functional knowledge in the areas of specialization and field of interest in Agricultural Production.

vi. The main objective is to train students to be knowledgeable, skillful and technical in the application of Agricultural Science principles and management with a view to improving crop and livestock industry:

vii. Provide technical knowledge and vocational skills necessary for Agricultural, commercial and economic development.

viii. Give training and impart the necessary skills to individuals who shall be self-reliant economically (F.R.N 2006).

In order to achieve these objectives the curriculum content at SSS level consists of three major concepts of production protection and economics. Topics organized into units: Learning-by- doing is emphasized in the curriculum and series of activities suggested to ensure the development of psychomotor skills in the subjects by the students. The programme further recommended that:

i. $\quad$ Each student be guaranteed adequate equipment farm space farm structure and regular supply of fertilizer and chemicals feeds.

ii. Student achievement should be continuously assessed through various forms of test and during field and laboratory practical.

iii. Each student should keep at least two farm animals. And

Individual assessment should be carried out for activities in crop production while group assessment should be restricted to performance in animal production activities. How many 
schools carry out the above recommendations in teaching the subjects. It was observed that many schools authorities show nonchalant attitudes towards the provision of needed tools equipment and farm inputs required for effective agricultural practices in schools. At tertiary level agricultural education is being studies at Universities polytechnics monotechnics Colleges of Education and Agricultural Research Institute among others. These institutes produce high-level manpower in different areas of agriculture for the country's agricultural development.

The major problem affecting tertiary institutions is their inability to meet the nation's need for agricultural education manpower demand. Luke-warm attitude of the government to promote the course of agricultural Education since there is an acute need to produce enough food for the teaming population .it is hoped that much encouragement will be given to the study of agricultural education in higher institutions. For without the adequately trained teachers of agriculture the younger generation may continue apathy for agriculture as a profession. Presently in Nigeria, pupils are expected to take agricultural science in the first three years in secondary school while agriculture at senior secondary school is optional for students. Therefore there is the need for restructuring of school's agricultural education programmes. Restructuring may mean using a tool to shape individuals thoughts, actions, attitudes, skills and knowledge. A tool to equip or enable one to functional education for useful living in a community or society (Hornby, 2000).

\section{Agricultural Education/Learning}

Agricultural education is to expose young people and to prepare them for occupation in different areas of agriculture. To achieve this the curriculum content should focus on skills aquisation in agricultural practices and the ability to meet global food supply. Agricultural education should encourage the production of livestock through biotechnology or selection and breeding. This must thereafter be further disseminated to end users through the extension services network which is yet another agricultural learning process.

The MDGs premier goal is to educate farmers for the eradication of extreme poverty and hunger by 2015(MDGs 2008). This clearly relates to agriculture and it is doubtful if this can be achieved without restructuring of agricultural practices which is basically characterized by a very low level of technology. Much restructuring of agricultural teaching/learning will therefore be required for timely achievement of this goal. Education is a major catalyst for human development. Through an exhibition and side Event at the high-level meeting on the millennium development goal (UNSeptember2010)UNESCO demonstrated how rapid advances in education can help to achieve all of the MDGs. Listed below are eight reasons why education is important to achieve all of the MDGs, with Education.

i. $\quad$ More people would grow and develop

ii. $\quad$ More people would learn and know

iii. More people would be equal and just

iv. More children would survive and live

iv. More mothers would be healthier 
v. More people would be able to combat illness

vi. More people would think of the future

vii. More people would work together

\section{Need For Restructuring Agricultural education}

Restructuring is to change the way in which something such as a government, business or system is organized such as the school curriculum has been restructured to include more science. Restructuring has to do with changing perception about Agricultural education; the need to change the way other people see or think about the courses of Agricultural education. The effort to restructure Agricultural education programme is principally both economic and social. To change the way other people see the programme we must first change the way we see the programme; and we must change the story we tell the world about the programme. If education is going to make a contribution to the current challenges, then the curricula content, teaching materials, methods and delivery approaches should be designed in such away as to equip the students with necessary skills and knowledge to tackle Agricultural challenges. There should be institutional innovations and changes to ensure that graduates produced from tertiary agricultural education have a restructured agricultural knowledge.

Salihu and Idris (2003) lamented on the education system practiced in Nigeria, the foundations of which were inherited from the British colonial masters which though changed but have not made the much needed impact technologically, economically, socially and politically. Technologically it may be argued that if a comparison is made between Nigeria and other countries who gained independence within the same period for example Malaysia, these countries are ahead while Nigeria is developing technologically at a snail space. This is because our farmers are still using local farm implements and crude methods of producing palm oil among others and toiling all day in field with knives, hoes and shovels which would not feed the nations population and think of exporting. There is need for mechanized farming while mechanized farming requires technical skills that could be obtained in technical and vocational schools the neglect of vocational and technical education is socially and economically injurious because it is robbing the nation the contributions the graduates would make on national development.

Economically, the country depends on crude oil sales while other sector of the economy in terms of agriculture is collapsing leaving us as consumer nation. Socially, there is moral decadence among youths and adults. Enoh (2000) cited by Mele (2007) Observed that moral values which include loyalty, trust, honesty, chaste and hard work have varnished among youths and adults in the society. Children and youths who grow up without the necessary restructure of attitudes become irresponsible and cannot be useful to the member of the society. The need for restructuring can never be over-emphasized. The days of using general education only as a tool to equip individuals for white collar jobs are gone as government at Local, State and Federal levels cannot provide bureaucratic jobs to youths that have graduated from colleges. It is very necessary to restructure the youth with functional education that will equip them with salable skills and knowledge to earn income to solve their basic needs and economic problems. Restructuring tool in agricultural education, which 
is vocational education will cater for skills, knowledge, attitudes including moral value that will make our youths successful in life.

It is no longer news that the nation's youth unemployment rates has been shooting up. The Federal government recently acknowledge that about 80 percent of Nigerian youths are unemployed and 10 percent under employed Given their corrupt and greedy life styles Nigeria's leaders do not seem to care about integrity or moral values. They go at predicting the future without creating it. As Drucker (2008) has observed, if you want to produce the future create it". Like unemployment, poverty is ravaging the society. Dike (2005) posited that, it has vastly been documented that more than 80 percent of Nigerians live on less than one dollar per day. There should be some form of school-work based learning incorporated in schools in Nigeria as integral art of national development strategy also empowering the people with technical skills would enhance their productivity and national developments.

\section{Components for Restructuring Agricultural education}

i. General agricultural education

ii. Linkage of agricultural education to the society

iii. Small agricultural business management and entrepreneurial training (F.R.N. 2006)

Agriculture is the basis of social and economic transformation of over $80 \%$ of the citizens in Nigeria (Ahmadu,1990). Majority of small-scale farmers are restricted to a vicious circle of poverty. In an attempt to solve this problem, the use of holistic component in the curriculum for each course in agricultural science education will restructure the programme.

\section{General Agricultural Education}

Okoro (1993) stated that General education provides the societal values, communicative and manipulative skills on which effective Vocational education is based. Without knowledge of reading, writing and mathematics, good vocational education cannot be acquired. Vocational education builds on a foundation of good general education. General agricultural education teaches values, skills and knowledge which each citizen should have in order to understand the society in which he or she lives and play an intelligent part in its affairs. Its aim is to develop the capacities latent in human nature and to coordinate their expression for the enrichment and progress of the society Agricultural Education through its allied courses such as forestry, horticulture, botany, fishery and ruminants and nonruminants will emphasize on best practices and programs that have direct bearing on environmental protection. Programs such as afforestation/deforestation, soil degradation, conservation farming, organic agriculture and other environmental practices are normally organized within the context of Agricultural Education provisions with the aim to protect, safeguard, and conserve the environment. Field practical training which is an integral part of agricultural training at tertiary levels of agricultural Education will provide skill for improved practices geared towards environmental sustainability. 


\section{Linkage of agricultural education to the society}

Temu, Mwanje and Mogotsi (2008) describe the linkage between agricultural education and society, agricultural education can be described as the process of preparing an individual to become a functional and acceptable member of society, two concepts are inbuilt in the definition of education, namely: creation of knowledge and experience, and growth and development. Unless tertiary agricultural education is able to respond to societal challenges and expectations, society will also have difficulties in understanding the roles of tertiary agricultural education, Diao, Hazell, Resnick and Thurlow. (2006).

The diagram below explains the linkage of agricultural education to the society.

\section{How education influences society}

participate in public debate

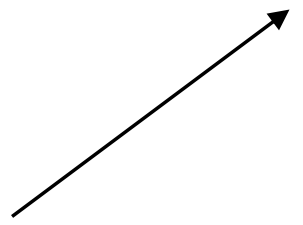

- Graduates gain employment

- Lecturers research, conduct outreach and

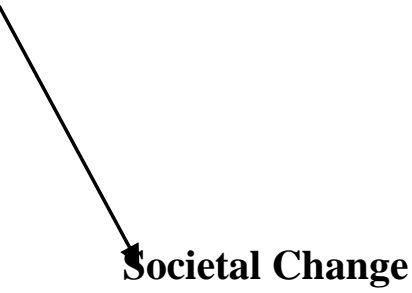

Local, national and long-term

\section{Educational Change}

Changes related to the teaching and learning process, its tools and institutions:

-Institutional innovation

- Curricula content

- Teaching materials

- Teaching and learning methods

- Delivery capacity (human resources and learning facilities)

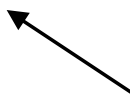

How society influences education:
Global trends

-Poverty alleviation

- Agriculture and rural Development

-Economic growth

-Demographic change

-Environmental change

- Globa conventions, Millennium

Development Goals and so on

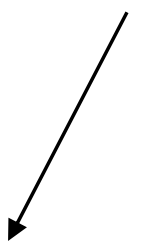

- Graduates gain employment

- Lecturers research, conduct outreach and participate in public debate

Figure 1:A model of interaction between society and agricultural education. Source: Rudebjer et al, (2005) 


\section{Shortfalls in current Secondary and Tertiary Agricultural Education}

Shortfalls in tertiary agricultural education have been described by Temu et al, (2008) and Chakeredza, Temu, Saka, Munthali, Muir-Leresche, Akinnifesi, Ajayi and Sileshi (2008) that the background of the current brain drain, it is observed that among other problems, the major constraints in tertiary agricultural education are as follows:

i. Poor staffing of institutions to meet the desired curriculum coverage

ii. The training is predominantly based on curricula adopted from countries that had colonies in Africa.

iii. The curricula were founded on an agricultural philosophy that aimed at the production of cash crops for consumption by the colonizing countries. Teaching mode is not learner- centred

iv. There is very little interaction with farming communities.

In fact, most of the universities are located in towns where there are no farming communities to work with nearby. In most cases the farming community is not involved in the design and delivery of agricultural curricula and there is absence of Private Sector involvement in the design and delivery of agricultural curricula. As a result, it is not surprising that tertiary agricultural institutions have so far done very little in the integration of climate change issues into tertiary agricultural education. There is a need to rethink and transform the tertiary agricultural education system so that it becomes responsive to the needs of the society.

The nature of teaching and learning in agriculture call for demonstration and practical of which the use of instructional materials is very imperative. But there is a persistent problem of effective utilization of these materials by teachers in schools. Omotunde (1996) reported that Agricultural science is an applied science with a lot of practical activities which students must participate so as to acquire practical skills and experience but too often the teachers of Agriculture teach it without the use of instructional material because the ingenuity necessary to improvise apparatus and find substitutes for materials is not found in many of them. Longe (2010) stated that though trained teachers are aware of the importance of the use of instructional materials in teaching process, but despite their exposure to those materials, teachers develop negative attitude towards their usage.

\section{Small agricultural business management and entrepreneurial training}

In order to achieve one of the goals of vocational objectives that is to make the individual self-reliant economically, the individual has to acquire skills and knowledge in small business management and entrepreneurial training. Such as poultry, fisheries, crop production Entrepreneurial training means equipping individuals with skills, knowledge and attitudes plus finance to create a business from raw-materials of his/her own ideas (Aluwong, 2009). It is a training that enables the individuals to take risk, opportunities in divers' areas. This type of training will include:-Technical skills; Management skills and Knowledge of lines of business (Mamuda\& Aliyu, 2000). 


\section{Recommendations and Suggestion}

- $\quad$ Individuals must develop willingness to imbibe the restructuring process to be a way of life and keep in focus the effectiveness of the programme.

- $\quad$ Continuity of government programmes; ie. Restructuring needs to be promoted until it has become a way of life in the individuals.

- Government should formulate policy that will look into programme restructured for the betterment of agricultural education.

- Government should restructure Dynamic curriculum for Agricultural education so as to burst agricultural education and to create a way for food security.

- $\quad$ Career guidance for Agricultural education programme in other to encourage student participation in studying agriculture.

- Teacher's should be given awareness of the overall aims and intentions of the curriculum for effective teaching of the courses.

- $\quad$ Adequate teaching aides and resources for learning should be available to suit the programme and to ease learning also to stimulate students learning.

\section{References}

Ahmadu, R. (1990). Agriculture in Nigeria, The role local participation can play to make it move. A paper presented in facilitators National workshop on participation Approach in Agriculture and Rural Development Jos, Nigeria.

Aluwong, S.W. (2009). Entrepreneurship, Education and Vocational and Technical Teachers Pre-Service Preparation. Jos. Faculty of Education.

Chakeredza, S., A.B. Temu, J.D.K. Saka, D.C. Munthali, K. Muir-Leresche, F.K. Akinnifesi, O.C.Ajayi and G. Sileshi, (2008). Tailoring tertiary agricultural education for sustainable development in Sub-Saharan Africa: Opportunities and Challenges. Scientific Research Essay, 3(8): 326- 332.

Chakeredza, S., A.B. Temu,YayeA,Mukingwa S, and Saka JDK (2009). Mainstreaming climate change into Agricultural Education: challenges and perspective.ICRAF Working paper no. 82 Nairobi, Kenya; World Agro Forestry Centre.

CAST (2004). Interpretative summary: Challenges and Opportunities for Agriculture. Task force report 141, May 2004.Available at http://www.C.Garn.U-ag-position paper pdf. Retrieved on 26-09-2011.

Diao, X., P. Hazell, D. Resnick and J. Thurlow. (2006). The role of agriculture in development: Implications for Sub-Saharan Africa. IFPRI, Development strategy and Governance Division, Discussion Paper No 29. Available at: http://www.ifpri.org. Accessed on 20.09.11. 
Dike, V.R. (2005). Vocational Education; Missing Link in Nigeria's development policy; on line: http://www.nigeria.villages square.com/articles/victor-dike/vocational-educationmissing-link-in-nigeria-s-development-p-2.html,Accessed on 20.09.11

Druker, S. D. (2008). Vocational Education, en,weikipedia.org/wiki/vocationaleducation;online-www.dest.giv.au/sectors/trainingskills/policy-issue-rewiews/keyissue/nts/glo/utoz.htm.

Federal Republic of Nigeria (2006). National Policy on Education. Abuja. NERDC Press.

Hornby, A. S. (2000). Oxford Advance, Learner's Dictionary. Oxford University Press.

Igwe, C.A. (2010). Climate Change and the need for Curriculum Development in Agricultural Sciences. Workshop on UNN Talks Climate Change.

Mamuda, A. and Aliyu, M. (2007).Entrepreneurial Education towards the Attainment of Needs objectives in Federal College of Education. Potiskum. Nigerian Journal of Technology Teacher Education.

Mamuda, A. and Aliyu, M. (2009). Global warming and the impacts of climate change on vulnerable communities and sectors of economic growth. Paper presented at the 2nd ANAFE International Symposium on "Mainstreaming Climate Change into Agricultural and Natural Resources Management Education: Tools, Experiences and Challenges" Held at Capital Hotel Lilongwe, Malawi from the 28th July to 1st August 2008.

Mele, H.D. (2007). Morality and HIV/AIDS, Challenges for Women as change Agents. Gombe. Federal College of Education Technical.

Longe, M. (2010). Reducing Poverty in Nigeria. Retrieved Sept 22, 2011 from http://www.championsfornigeria.org/cfn/

Olowa, O.W. (2002). Facilities and Academic Achievement of Student in the Study of Agricultural Science in Selected Secondary Schools of Ondo State A paper Presented at the School of Education Seminar Series F.C.E. (T) Akoka. June 2002.

Omotunde, Y. A. (1996).Self Sufficiency in Food Production and the Changing Curriculum in Agricultural Education in Nigeria. Associated for Agricultural Education Held at the I.A.R and T. Moor Plantation. Ibadan.

Okorie, J. U. (2001). Vocational Industrial Education, Bauchi Journal of Leaque of Researchers in Nigeria (LRN).

Okoro, O.M. (1993). Principles and Methods in Vocational and Technical Education Nsukka. University Trust Publishers. 
Rudebjer, P., A.B. Temu and J. Kung'u, (2005). Developing Agro forestry Curricula: a practical guide for academic institutions in Africa and Asia. Bogor, World Agro forestry Centre. $53 \mathrm{pp}$.

Salihu, M.N.andIdris, H. (2003). Limitations of Educational Development in Nigeria in the $21^{\text {st }}$ Century Journal of Issues in Technical Teacher.

Temu, A., I. Mwanje and K. Mogotsi. (2003). Improving Agriculture and Natural Resources Education in Africa: A stitch in Time. Nairobi, Kenya: World Agro forestry Centre (ICRAF).

Temu, A.B. and S. Chakeredza, (2008). Institutionalization challenges for climate change management. Paper presented at the 2nd ANAFE International Symposium on "Mainstreaming Climate Change into Agricultural and Natural Resources Management Education: Tools, Experiences and Challenges" Held at Capital Hotel Lilongwe, Malawi from the 28th July to 1st August 2008.

UNESCO (2010). http://www.unesco.org/new/en/education Retrieved Sept 22, 2011. 